\title{
Ambient fine particulate matter exposure induces reversible cardiac dysfunction and fibrosis in juvenile and older female mice
}

\author{
Guohua Qin', Jin Xia', Yingying Zhang ${ }^{1}$, Lianghong Guo², Rui Chen ${ }^{3}$ and Nan Sang ${ }^{1 *}$
}

\begin{abstract}
Background: Cardiovascular disease is the leading cause of mortality in the advanced world, and age is an important determinant of cardiac function. The purpose of the study is to determine whether the $\mathrm{PM}_{2.5}$-induced cardiac dysfunction is age-dependent and whether the adverse effects can be restored after $\mathrm{PM}_{2.5}$ exposure withdrawal.

Methods: Female C57BL/6 mice at different ages (4-week-old, 4-month-old, and 10-month-old) received oropharyngeal aspiration of $3 \mathrm{mg} / \mathrm{kg}$ b.w. PM 2.5 every other day for 4 weeks. Then, 10-month-old and 4-week-old mice were exposed to $\mathrm{PM}_{2.5}$ for 4 weeks and withdrawal $\mathrm{PM}_{2.5} 1$ or 2 weeks. Heart rate and systolic blood pressure were measured using a tailcuff system. Cardiac function was assessed by echocardiography. Left ventricles were processed for histology to assess myocardial fibrosis. ROS generation was detected by photocatalysis using 2,7'-dichlorodihydrofluorescein diacetate (DCFHDA). The expression of cardiac fibrosis markers (Col1a1, Col3a1) and possible signaling molecules, including NADPH oxidase 4 (NOX-4), transforming growth factor $\beta 1$ (TGF 31 ), and Smad3, were detected by qPCR and/ or Western blot.

Results: $\mathrm{PM}_{2.5}$ exposure induced cardiac diastolic dysfunction of mice, elevated the heart rate and blood pressure, developed cardiac systolic dysfunction of 10-month-old mice, and caused fibrosis in both 4-week-old and 10-month-old mice. PM 2.5 exposure increased the expression of Col1a1, Col3a1, NOX-4, and TGF $\beta 1$, activated Smad3, and generated more reactive oxygen species in the myocardium of 4-week-old and 10-month-old mice. The withdrawal from $\mathrm{PM}_{2.5}$ exposure restored blood pressure, heart rate, cardiac function, expression of collagens, and malonaldehyde (MDA) levels in hearts of both 10-month-old and 4-week-old mice.

Conclusion: Juvenile and older mice are more sensitive to $\mathrm{PM}_{2.5}$ than adults and suffer from cardiac dysfunction. $\mathrm{PM}_{2.5}$ exposure reversibly elevated heart rate and blood pressure, induced cardiac systolic dysfunction of older mice, and reversibly induced fibrosis in juvenile and older mice. The mechanism by which $\mathrm{PM}_{2.5}$ exposure resulted in cardiac lesions might involve oxidative stress, NADPH oxidase, TGF $\beta 1$, and Smad-dependent pathways.
\end{abstract}

Keywords: Particulate matter, Cardiac, Fibrosis, Reversible, Different age

\section{Background}

Air pollution, mostly by fine particulate matter $\left(\mathrm{PM}_{2.5}\right)$, leads to 3.3 million premature deaths per year worldwide, predominantly in Asia [1]. Epidemiological evidence supports a robust association between exposure to $\mathrm{PM}_{2.5}$ and cardiovascular diseases morbidity and mortality, such as myocardial infarction, heart failure, heart attacks, stroke, heart rhythm disturbances, and

\footnotetext{
*Correspondence: sangnan@sxu.edu.cn

${ }^{1}$ College of Environment and Resource, Research Center of Environment and Health, Shanxi University, Taiyuan, Shanxi 030006, People's Republic of China Full list of author information is available at the end of the article
}

sudden death $[2,3]$. However, the physicochemical properties of ambient $\mathrm{PM}_{2.5}$ in different regions varies because of a number of factors including local geography, proximity to emission sources, and meteorology. Even in the same region, $\mathrm{PM}_{2.5}$ from different seasons appears to have different chemical composition. It has been reported that seasonal variation in the association between $\mathrm{PM}_{2.5}$ and cardiovascular hospitalization [4]. Furthermore, $\mathrm{PM}_{2.5}$ does not affect all people equally. Several studies have suggested that susceptible individuals are at greater risk for $\mathrm{PM}_{2.5}$-associated cardiovascular morbidity and mortality including the elderly, women, and 
patients with preexisting coronary artery disease and diabetes $[5,6]$.

Recent studies have demonstrated that exposure to $\mathrm{PM}_{2.5}$ promotes systolic and diastolic dysfunction [7, 8], and exposure to carbon black impairs cardiac function in senescent mice [9]. Furthermore, exposure to diesel exhaust or $\mathrm{PM}_{2.5}$ during early life can cause significant cardiovascular dysfunction in adulthood [10, 11]. However, the susceptibility of individuals of different ages to cardiovascular disease caused by $\mathrm{PM}_{2.5}$ exposure has not been investigated. We hypothesized that $\mathrm{PM}_{2.5}$ exposure may induce different effects in different life phases, such as juvenile, adult, and older subpopulations.

The specific molecular mechanisms of $\mathrm{PM}_{2.5}$-induced cardiotoxicity effects are still under active investigation. Numerous investigations have elucidated potential biological mechanisms, whereby exposure to $\mathrm{PM}_{2.5}$ may modulate disease susceptibility, including the progression of atherosclerosis, inflammation, thrombosis, systemic vascular dysfunction, and epigenetic changes [12]. Cardiac fibrosis is a common phenotype found in several cardiac diseases, including myocardial infarction and heart failure. It is characterized by the adverse accumulation of collagen and other extracellular matrix proteins. In addition to the loss of contractile capacity, inhalation of $\mathrm{PM}_{2.5}$ is associated with adverse ventricular remodeling and worsening of cardiac fibrosis [7, 11]. Transforming growth factor $\beta 1$ (TGF $\beta 1$ ), a critical regulator of fibroblast phenotype and function, acts through Smad-dependent or independent pathways [13]. However, the mechanisms underlying the cardiac fibrosis effects of $\mathrm{PM}_{2.5}$ are unclear.

Several previous studies of seasonal patterns of cardiovascular disease (CVD) indicated a peak of CVD in winter months $[4,14,15]$. We found seasonal variation in associations between collagen expression and $\mathrm{PM}_{2.5}$ exposure in $\mathrm{H} 9 \mathrm{C} 2$ cells in our pilot experiment. The strongest effect on collagen expression was observed after treatment with $\mathrm{PM}_{2.5}$ from winter (Additional file 1: Figure S1). Accordingly, winter $\mathrm{PM}_{2.5}$ was used for in vivo experiments in mice in the present study. The dose of $\mathrm{PM}_{2.5}$ used in the present study was based on the following reasoning. As reported, respiratory volume of one mouse for 2 days reaches $0.259 \mathrm{~m}^{3}$ [16]. According to the Chinese ambient air quality secondary standards (GB3095-2012) of $\mathrm{PM}_{2.5}\left(75 \mu \mathrm{g} / \mathrm{m}^{3}\right)$, the amount of $\mathrm{PM}_{2.5}$ inhalation for each mouse over 2 days is $19.425 \mu \mathrm{g}$. Therefore, $\mathrm{PM}_{2.5}$ exposure concentration for mouse (about $20 \mathrm{~g}$ b.w.) every 2 days should be $0.97 \mathrm{mg} / \mathrm{kg}$ (b.w.). The dose used in the present study was about 3 fold of secondary standards or more than 3.6 fold when considering the deposition fraction [17]. However, the $\mathrm{PM}_{2.5}$ concentration could exceed $300 \mu \mathrm{g} / \mathrm{m}^{3}$ during the polluted periods in Beijing [18] or other cities in China (http:// 113.108.142.147:20035/emcpublish/). The average concentration of $\mathrm{PM}_{2.5}$ in northern China with non-haze weather was $161 \mu \mathrm{g} / \mathrm{m}^{3}$ [19], and the level with haze weather reached $692 \mu \mathrm{g} / \mathrm{m}^{3}$ [20].

Therefore, the purpose of this study was: (1) to determine whether the $\mathrm{PM}_{2.5}$-induced cardiac dysfunction is age-dependent; (2) to examine whether the above-mentioned effects could be restored after $\mathrm{PM}_{2.5}$ exposure withdrawal; (3) to determine the potential mechanism of susceptibility to $\mathrm{PM}_{2.5}$ exposure.

\section{Results}

Exposure to $\mathrm{PM}_{2.5}$ elevates heart rate and systolic blood pressure of 10-month-old mice

For the heart rate of 4-week-old mice, 4 weeks of $\mathrm{PM}_{2.5}$ exposure caused a significant increase compared with pre-exposure but a non-significant increase compared with age-matched control group (Fig. 1a). The systolic blood pressure of 4-week-old mice was not affected by $\mathrm{PM}_{2.5}$ during 4 weeks of exposure (Fig. 1b). Neither heart rate nor the systolic blood pressure of 4-monthold mice was changed after $\mathrm{PM}_{2.5}$ exposure within the 4 weeks observation period. For 10-month-old mice, 2 weeks of $\mathrm{PM}_{2.5}$ exposure caused a significant increase in the heart rate compared with pre-exposure or agematched control group (Fig. 1a). The heart rate of 10-month-old mice was significantly higher than 4-month-old mice after $\mathrm{PM}_{2.5}$ exposure (Fig. 1a). The systolic blood pressure of 10-month-old mice was elevated after 4 weeks of exposure compared with age-matched control group (Fig. 1b). The systolic blood pressure of 10-month-old mice was significantly higher than both 4-week-old and 4-month-old mice after $\mathrm{PM}_{2.5}$ exposure (Fig. 1b). Interestingly, the heart rate of 10-month-old mice decreased to base level after withdrawal from $\mathrm{PM}_{2.5}$ exposure for 2 weeks (Fig. 1c). The systolic blood pressure of 10-month-old mice was almost completely restored after withdrawal from $\mathrm{PM}_{2.5}$ exposure for only 1 week (Fig. 1d).

\section{Exposure to $\mathrm{PM}_{2.5}$ induces cardiac dysfunction in mice}

The data obtained from echocardiography are presented in Fig. 2. The ratio of peak early diastolic flow velocities and peak early motion wave values $\left(E / E^{\prime}\right)$ was significantly changed in mice at different ages after $\mathrm{PM}_{2.5}$ exposure (Fig. 2a). The E/E' of 10-month-old mice and 4-week-old mice was restored after withdrawal from $\mathrm{PM}_{2.5}$ exposure for 2 weeks (Fig. 2c, e). $\mathrm{PM}_{2.5}$ exposure caused a significant decrease in the ejection fraction (EF) of 10-month-old mice compared to age-matched control group. (Fig. 2b). The EF of 10-month-old mice was significantly lower than both 4-week-old and 4-monthold mice after $\mathrm{PM}_{2.5}$ exposure (Fig. 2b). The EF of 


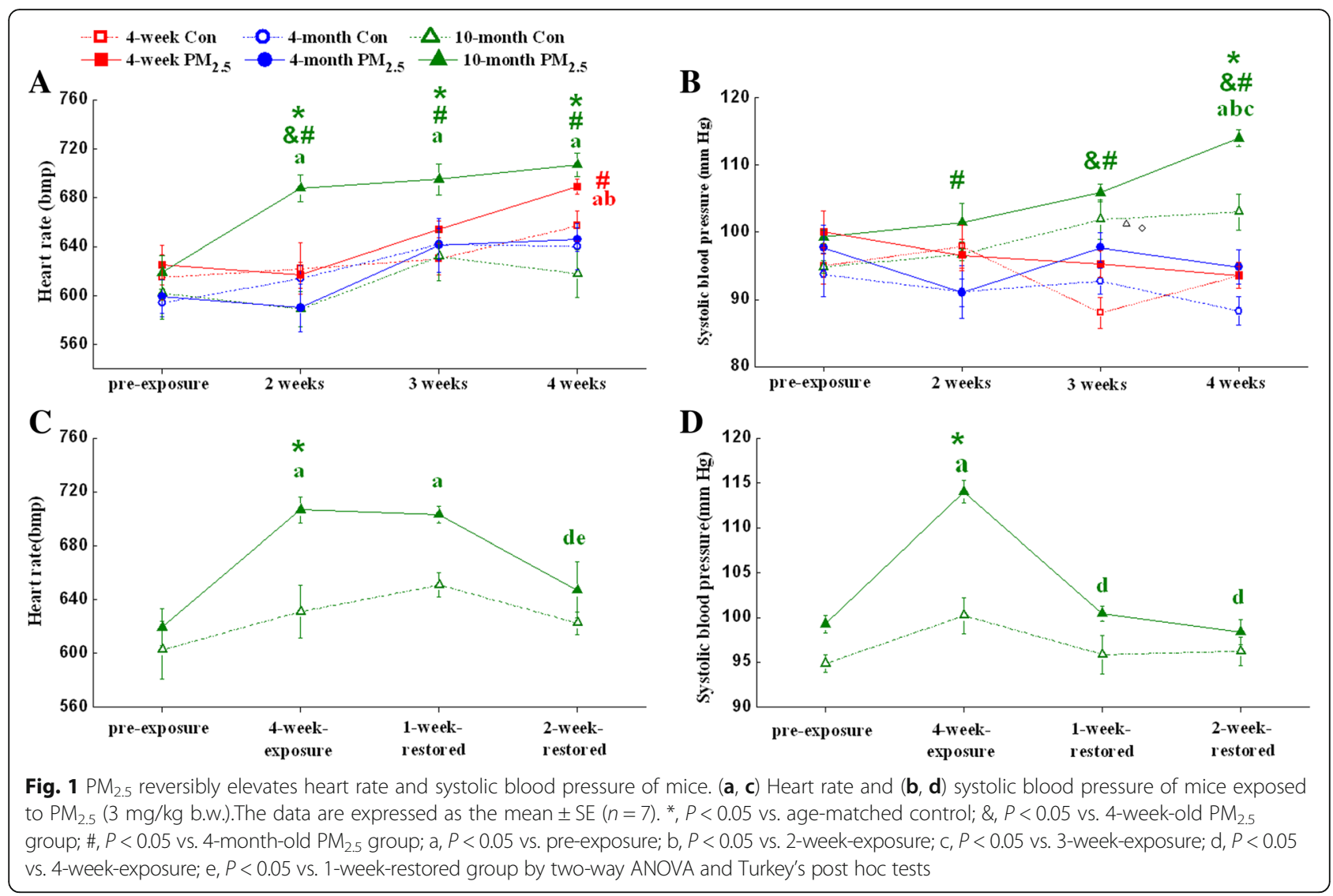

10-month-old mice was restored after withdrawal from $\mathrm{PM}_{2.5}$ exposure for 1 week (Fig. $2 \mathrm{~d}$ ).

Exposure to $\mathrm{PM}_{2.5}$ induces cardiac fibrosis in 4-week-old and 10-month-old mice

Histological examination of $\mathrm{PM}_{2.5}$-exposed mouse hearts stained with Masson's trichrome revealed increased collagen deposition/myocardial fibrosis (Fig. 3). The hearts from $\mathrm{PM}_{2.5}$-exposed 4-week-old and 10-month-old mice showed interstitial fibrosis distributed diffusely across the left ventricular free wall (Fig. 3a). Quantification of the fibrotic area demonstrated that fibrosis was significantly greater in the $\mathrm{PM}_{2.5}$-exposed 4-week-old and 10-month-old mice than the corresponding control mice (Fig. 3b). The fibrotic area in hearts from 10-month-old mice was significantly greater than in hearts form 4-month-old mice after $\mathrm{PM}_{2.5}$ exposure (Fig. 3b). The fibrosis area reduced in 10-month-old mice after withdrawal from exposure to $\mathrm{PM}_{2.5}$ for 2 weeks (Fig. 3A, e-f; C). The fibrosis area was reduced in 4-week-old mice after withdrawal from exposure to $\mathrm{PM}_{2.5}$ for 2 weeks (Fig. 3A, i-j; D).

\section{Exposure to $\mathrm{PM}_{2.5}$ induces cardiac fibrosis marker} expression in 4-week-old and 10-month-old mice $\mathrm{PM}_{2.5}$ exposure of 4-week-old and 10-month-old mice led to increased transcription of Col1a1 and Col3a1, the major structural collagen in the myocardium, suggesting that $\mathrm{PM}_{2.5}$ exposure alters gene expression consistent with a profibrotic phenotype (Fig. 4a, b). Western blot analyses confirmed increased protein expression of Colla1 and Col3a1 in $\mathrm{PM}_{2.5}$-exposed 10-month-old mice and Colla1 in $\mathrm{PM}_{2.5}$-exposed 4-week-old (Fig. 4c, d). Furthermore, consistent with above results regarding cardiac dysfunction and collagen deposition, the expression of Colla1 and Col3a1 of 10-month-old and 4-week-old mice were restored after withdrawal from exposure to $\mathrm{PM}_{2.5}$ for one or 2 weeks (Fig. 4c-f).

$\mathrm{PM}_{2.5}$ induces ROS in hearts of 4-week-old and 10-monthold mice

The generation of ROS induced by $\mathrm{PM}_{2.5}$ was detected by photocatalysis using an ROS-sensitive probe $-2^{\prime}, 7^{\prime}$ dichlorodihydrofluorescein diacetate (DCFHDA, Invitrogen). The ROS levels in the hearts of 4-week-old and 10-month-old mice exposed to $\mathrm{PM}_{2.5}$ were significantly increased compared to those of the corresponding control mice and 4-month-old mice after $\mathrm{PM}_{2.5}$ exposure (Fig. 5).

$\mathrm{PM}_{2.5}$ induces inflammation and oxidative damage in hearts and lungs of 4-week-old and 10-month-old mice In order to indicate whether the occurrence of oxidative damage is a consequence of the local oxidative stress of 

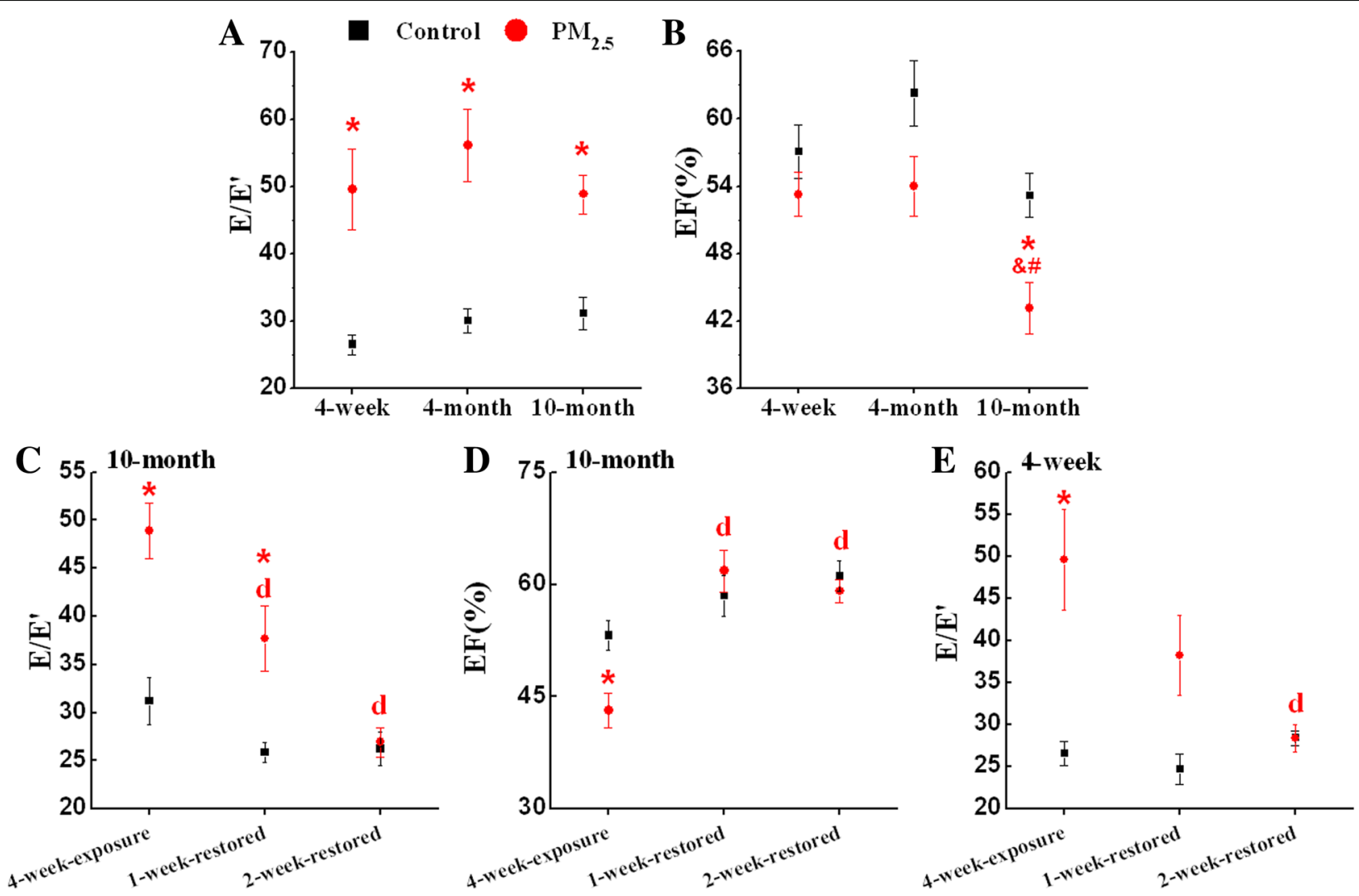

Fig. $2 \mathrm{PM}_{2.5}$ reversibly induces cardiac dysfunction in mice. (a) E/E' of different age mice; (b) EF of different age mice; (c) E/E' of 10-month-old mice; (d) EF of 10-month-old mice; (e) E/E' of 4-week-old mice. The data are expressed as the mean $\pm \mathrm{SE}(n=6 \sim 9)$. E/E', the ratio of peak early diastolic flow velocities and peak early motion wave values; EF, ejection fraction. ${ }^{*}, P<0.05$ vs. age-matched control by two-way ANOVA and Turkey's post hoc tests; $\&, P<0.05$ vs. 4-week-old $P M_{2.5}$ group; \#, $P<0.05$ vs. 4-month-old $P_{2.5}$ group; $d, P<0.05$ vs. 4-week-exposure by two-way ANOVA and Bonferroni's post hoc tests

lungs, we detected the mRNA levels of TGF $\beta 1$ and interleukin 6 (IL-6), and MDA levels in hearts and lungs. The mRNA levels of TGF $\beta 1$ were significantly increased in both lungs and hearts of 4-week-old and 10-month-old mice after $\mathrm{PM}_{2.5}$ exposure (Fig. 6a, b). The highest expression of TGF $\beta 1$ mRNA was observed in hearts of 10-month-old mice after $\mathrm{PM}_{2.5}$ exposure (Fig. 6b). The mRNA levels of IL- 6 were significantly increased in lungs of all exposed groups mice and in hearts of 4-week-old and 10-month-old mice after $\mathrm{PM}_{2.5}$ exposure (Fig. 6c, d).

The MDA levels in the hearts and lungs of 4-week-old and 10-month-old mice exposed to $\mathrm{PM}_{2.5}$ were significantly higher than in aged-matched controls (Fig. 7a, b). The MDA levels in hearts and lungs of 10-month-old mice decreased to base level after withdrawal from exposure to $\mathrm{PM}_{2.5}$ for 1 week (Fig. 7c-d). The MDA levels of 4-week-old mice did not change compared to corresponding controls after withdrawal from exposure to $\mathrm{PM}_{2.5}$ for one or 2 weeks (Fig. 7e-f).
$\mathrm{PM}_{2.5}$-induced cardiac fibrosis is associated with NOX4ROS-TGF $\beta 1$-Smad signaling

Western blotting was used to detect the protein expression of possible signaling molecules involved in $\mathrm{PM}_{2.5}$-induced cardiac fibrosis. NOX-4 and TGF $\beta 1$ protein levels were significantly increased in the hearts of 4-week-old and 10-month-old mice after $\mathrm{PM}_{2.5}$ exposure (Fig. 8a-c). After exposure for 4 weeks, $\mathrm{PM}_{2.5}$ treatment activated Smad3 in the hearts of 4-week-old and 10-month-old mice (Fig. 8a \& d). No significant differences in the protein levels of NOX-4 or TGF $\beta 1$ or in the phosphorylation of Smad3 were observed in the hearts of 4-month-old mice compared with the control group (Fig. 8).

\section{Discussion}

The results of our present study provide evidence that $\mathrm{PM}_{2.5}$ aspiration induced cardiac dysfunction and fibrosis in 4-week-old and 10-month-old mice, and the adverse effects could be resolved after $\mathrm{PM}_{2.5}$ exposure withdrawal. Cardiovascular disease is the leading cause 


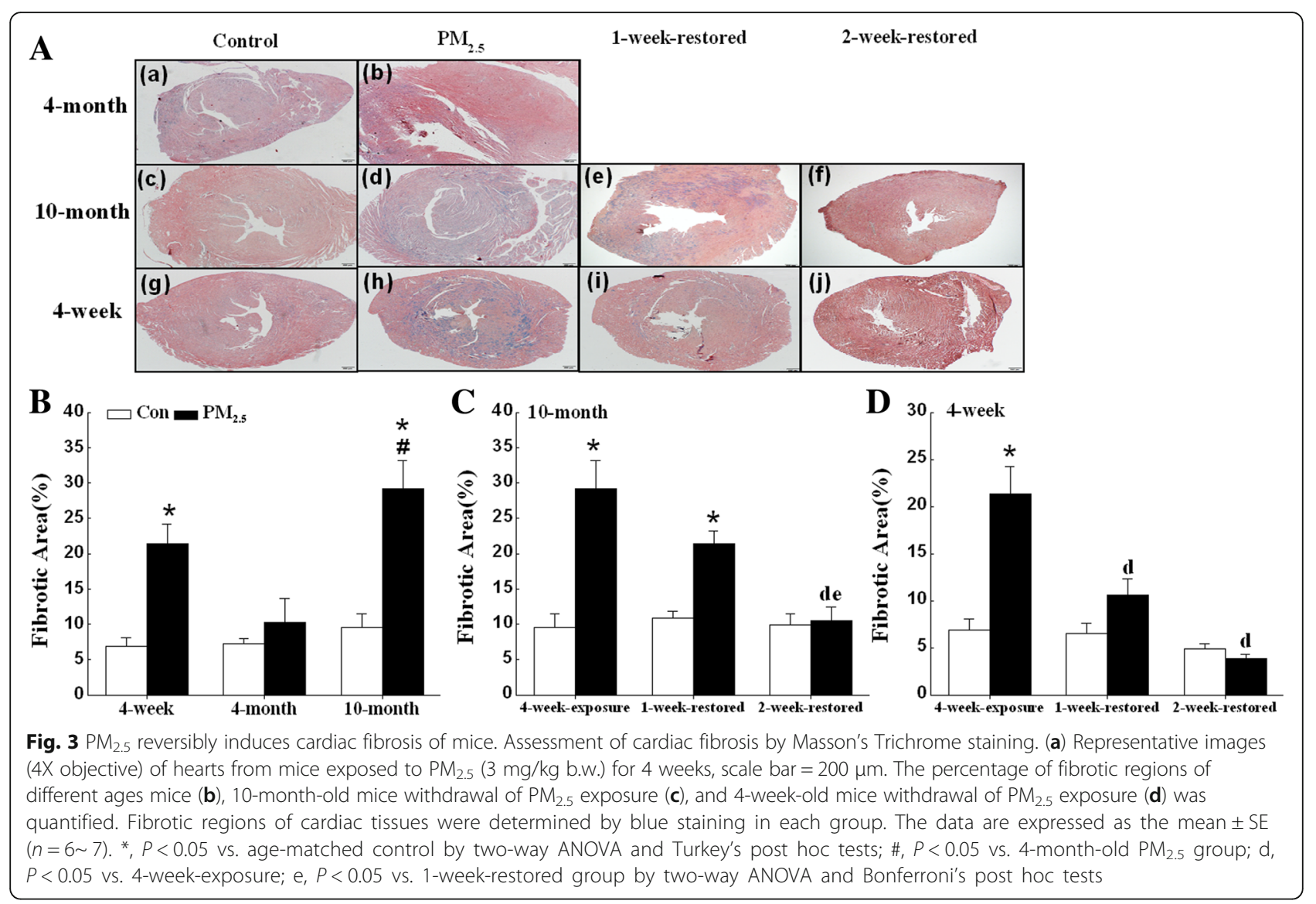

of mortality in the advanced world, and age is an important determinant of cardiac function. The morbidity and mortality rates associated with $\mathrm{PM}_{2.5}$-induced cardiovascular disease are significantly higher in the elderly than in adults. Based on preliminary epidemiologic evidence, infants less than 2 years old and adults over 65 years old are the most susceptible subpopulations to PM [21]. Numerous findings support the association between PM exposure and electrocardiogram abnormalities in elderly subjects [22]. Several epidemiological studies have demonstrated associations between acute and chronic $\mathrm{PM}_{2.5}$ exposure and the elevation of heart rate and blood pressure, especially among elderly or susceptible individuals $[5,23,24]$. However, the effects of childhood air pollution exposure on cardiovascular risk in human populations are not well defined.

Most studies on the cardiac effects of PM are performed in susceptible models, such as hypertensive $[25,26]$, ligation of coronary arteries [27], and gene deficient animals $[28,29]$. In the present study, 4-week-old, 4-month-old, and 10-month-old mice were employed as juvenile, adult, and older subpopulations, respectively. It is reported that during the juvenile stages, the valve, left atrial size, left ventricular end-diastolic dimension, aortic root, and ascending aorta dimensions show linear growth and, during the adult stages, the dimensions plateau [30]. There is evidence for atrial hypertrophy and dilatation, and LV wall thickness increases with age in older mice. Other age-dependent cellular changes reported in aging rodents include fibroblast proliferation, collagen accumulation, and interstitial fibrosis in both the atria and the ventricles [31]. Our data revealed that subchronic exposure to $\mathrm{PM}_{2.5}$ significantly increased the heart rate and systolic blood pressure in older mice. Furthermore, the $\mathrm{PM}_{2.5}$ effects on heart rate and blood pressure of 10 -month-old mice were reversible. This finding is consistent with previous studies showing that chronic inhalation exposure to concentrated ambient particulate matter increased heart rate and blood pressure in C57BL/6 mice [7, 32]. Ying et al. reported that chronic exposure to concentrated ambient particulate matter (CAP) significantly increased blood pressure of spontaneously hypertensive rats, and withdrawal from CAP exposure restored blood pressure [26]. In combination, these data provide strong evidence that exposure to $\mathrm{PM}_{2.5}$ may have significant effects on elderly because they are more susceptible to cardiovascular disease.

Wold and colleagues reported that a 9-month inhalation exposure to CAP resulted in systolic and diastolic dysfunction [7]. In utero and early life exposure to diesel 


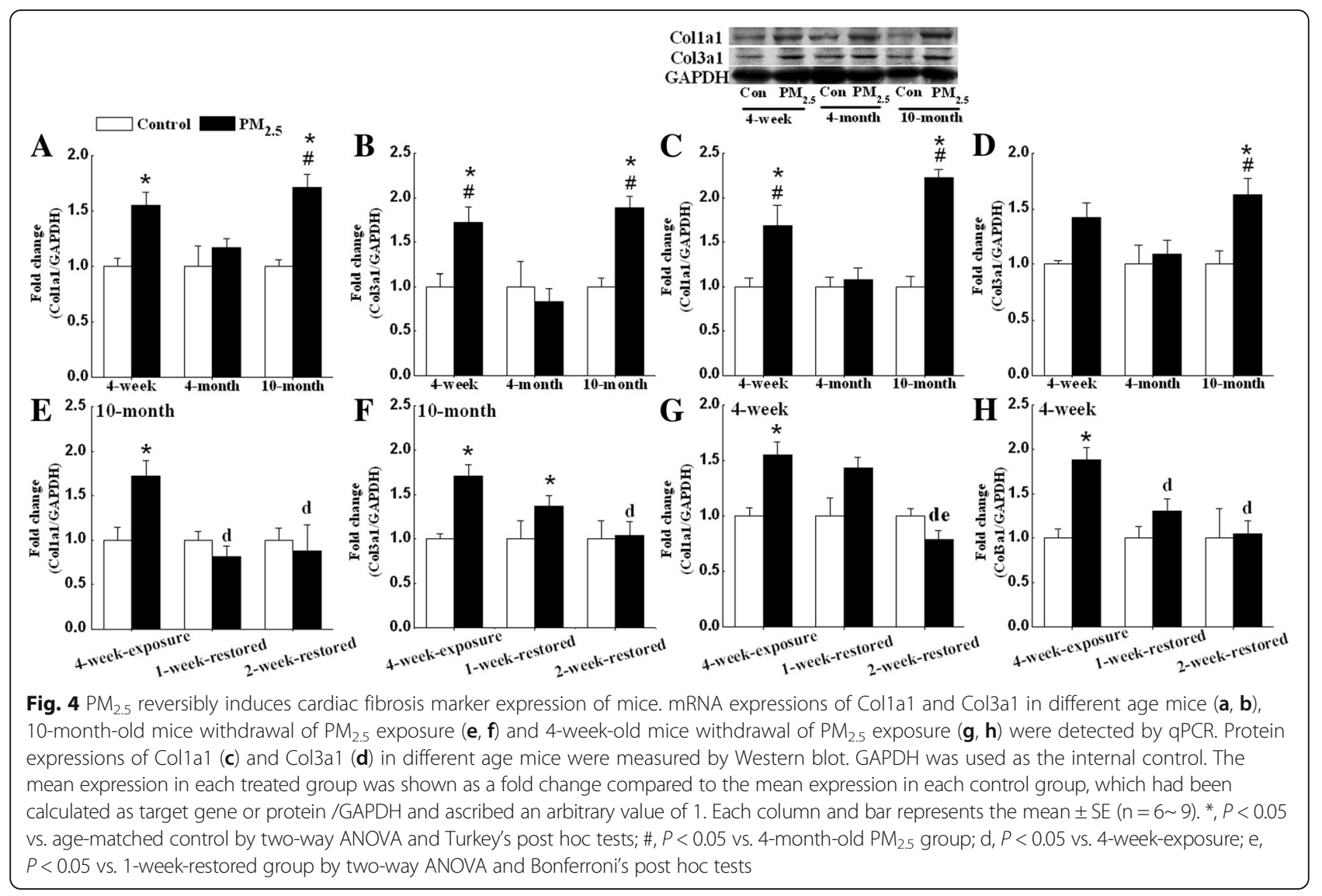

exhaust or $\mathrm{PM}_{2.5}$ induces adult cardiac dysfunction $[10,11]$. In the present study, the hearts of $\mathrm{PM}_{2.5}$-exposed mice of different ages displayed a phenotype of diastolic dysfunction, indicated by the index of $E / E^{\prime}$ ratios. The $\mathrm{E} / \mathrm{E}$ ' ratio is a reliable index for detecting diastolic dysfunction [33]. EF is a basic parameter that assess systolic functions of the heart. Decreases in EF suggest that subchronic exposure to $\mathrm{PM}_{25}$ induced systolic dysfunctions only in 10-month-old mice. Furthermore, $\mathrm{PM}_{2.5}$-induced cardiac dysfunction of 10-month-old and 4-week-old mice could be restored after $\mathrm{PM}_{2.5}$ withdrawal. It is in accordance with previous study that withdrawal from CAP exposure restored cardiac function in spontaneously hypertensive rats [26]. Some pharmacological agents/genetic modification could reduce $\mathrm{PM}_{2.5}$-induced hypertension in rats $[8,34]$. It indicated that $\mathrm{PM}_{2.5}$-induced cardiac dysfunction is reversible.

We found that 10-month-old and 4-week-old mice developed more fibrosis following $\mathrm{PM}_{2.5}$-exposure. The impairment in heart function observed in 4-week-old and 10-month-old mice correlated with increases of collagen deposition. The increases in fibrillar collagen in the heart interstitium contribute to tissue stiffness, and increases in collagen deposition may contribute to impaired heart function. We observed $\mathrm{PM}_{25}$-induced fibrosis changes in 4-week-old and 10-month-old mice accompanied by increases in the gene expression of major structural collagen types (Colla1 and Col3a1) in the myocardium. Other studies have documented similar results with exposure to concentrated ambient PM [7, 35] and carbon black [9].

The heart rate, blood pressure, cardiac functional and structural changes, and molecular marker data showed that older mice are the most susceptible group to $\mathrm{PM}_{2.5}$. Similar results were observed with secondhand smoke or lipopolysaccharide (LPS) treatment. Secondhand smoke or LPS induce more cardiac dysfunction, fibrosis, inflammation, and oxidative stress in aged mice than in young mice [36, 37]. Aging-associated cardiac abnormalities are manifested as diastolic cardiac dysfunction, cardiac hypertrophy, and fibrosis, as well as impaired contractile function $[38,39]$. The negative effects of $\mathrm{PM}_{2.5}$ on older mice might accelerate the development of aging. Furthermore, our data showed that 4-week-old mice were more susceptible than 4-month-old mice. $\mathrm{PM}_{2.5}$ exposure induced cardiac fibrosis, elevated Col1a1 and Col3a1 expression in 4-week-old mice, but not in 4-month-old mice. One possible reason for the difference in susceptibility to $\mathrm{PM}_{2.5}$ of mice is their 


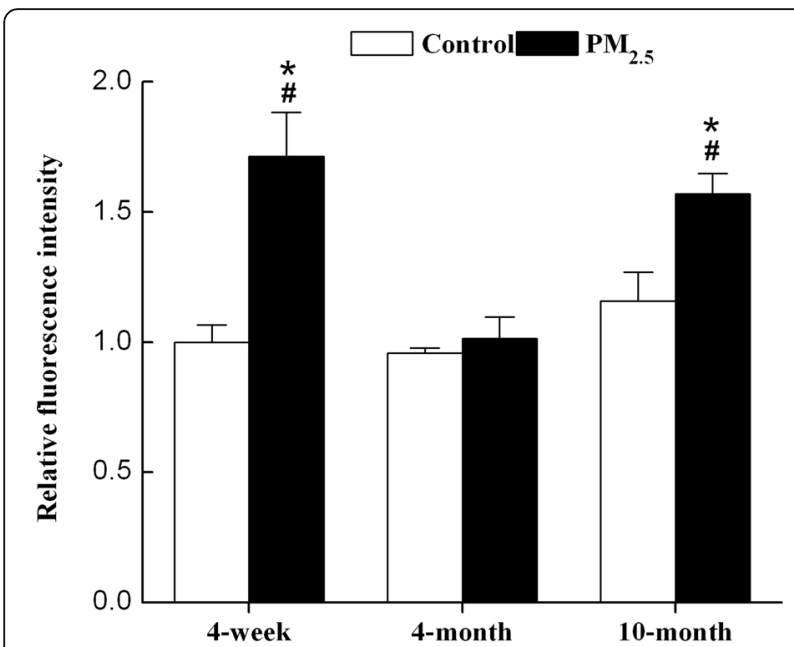

Fig. $5 \mathrm{PM}_{2.5}$ induces ROS generation in 4-week-old and 10-month-old mice. The generation of ROS by $\mathrm{PM}_{2.5}$ was detected by photocatalysis using the ROS-sensitive probe DCFHDA. Mean fluorescence units $(\mathrm{FLU}) / \mathrm{mg}$ protein in each treated groups was shown as a fold change compared to the mean value in the control group of 4-week-old mice, which had been ascribed an arbitrary value of 1. Each column and bar represents the mean \pm SE $(n=7 \sim 9)$. DCFHDA, 2',7'-dichlorodihydrofluorescein diacetate. ${ }^{*}, P<0.05$ vs. age-matched control by two-way ANOVA and Turkey's post hoc tests. \#, $P<0.05$ vs. 4 -month-old $\mathrm{PM}_{2.5}$ group by two-way ANOVA and Bonferroni's post hoc tests

differences in estrogen levels. It is well established that the incidence of cardiovascular disease is reduced in females prior to menopause, which may be due to estrogen levels [40]. Estrogen protects cardiomyocytes against angiotensin II-induced sensitization of hypertension [41]. In the present study, we observed that $\mathrm{PM}_{2.5}$ elevated non-significantly the estradiol 2 (E2) levels of 4-week-old and 4-month-old mice. The E2 levels of 10-month-old mice were lower than 4-month-old mice in $\mathrm{PM}_{2.5}$ groups (Additional file 2: Figure S2). It still needs further research to study whether male mice display different age-dependent responses from female mice. Another possible mechanism of $\mathrm{PM}_{2.5}$-induced cardiac functional changes might involve the role of ROS. Oxidative stress is increased in human heart failure and animal models of cardiac hypertrophy and fibrosis [42]. The heart consists of various types of cells, such as cardiomyocytes and nonmyocytes, including fibroblasts, endothelial cells, smooth muscle cells, and immune system-related cells [43]. ROS could be produced in cardiomyocytes or endothelial cells [44]. Our recent study has shown that $\mathrm{PM}_{2.5}$ dose-dependently induced ROS production in $\mathrm{H} 9 \mathrm{C} 2$ cells [45]. In the present study, $\mathrm{PM}_{2.5}$ induced ROS generation in hearts and lungs of 4-week-old and 10-month-old mice. These observations indicated that ROS and oxidative stress might play important roles in $\mathrm{PM}_{2.5}$-induced cardiac fibrosis.
Different potential mechanisms for PM-associated cardiovascular disease have been hypothesized as either activated by direct effects of pollutants on the cardiovascular system, or by indirect effects due to pulmonary oxidative stress and inflammatory responses [46]. In the present study, we observed the elevation of TGF $\beta 1$ and IL-6 mRNA expression and MDA levels in lungs and hearts of 4-week-old and 10-month-old mice. Although this does not exclude the possibility of direct particle translocation, it is possible that $\mathrm{PM}_{2.5}$ triggers the release of soluble inflammatory mediators from the lungs and subsequently causes cardiac inflammation through systemic inflammatory responses. Similarly, it is reported that extra-pulmonary effects due to carbon nanoparticles inhalation are dominated by indirect effects (particle-cell interactions in the lung) rather than direct effects (translocated carbon nanoparticles) [47].

ROS generation has been detected in rat ventricular myocytes exposed to diesel exhaust, and it is likely mediated through NADPH oxidase-dependent pathways [48]. $\mathrm{NADPH}$ oxidases are multisubunit enzymes that are largely distributed within heart cells [49]. NOX-4 is essential for the differentiation of human cardiac fibroblasts into myofibroblasts [42]. A similar phenomenon was observed in the present study by the examination of NOX-4 expression and direct measurement of intracellular ROS as DCFHDA-fluorescence in mice. Following activation, membrane-bound NADPH oxidase initiates single-electron transfers to molecular oxygen, resulting in the formation of ROS [50]. Our data showed that NOX-4 expression was increased in 4-week-old and 10-month-old mice after $\mathrm{PM}_{2.5}$ exposure. The increase in NOX-4 expression was accompanied by the elevation of TGF $\beta 1$ protein expression. ROS stimulates the release and activation of cytokines, such as TGF $\beta 1$ [51]. TGF- $\beta 1$ is expressed and released by many cell types, including cardiomyocytes, cardiac fibroblasts, and immune cells [52]. Cardiac tissue fibrosis in mice hearts is associated with an increased expression of the profibrotic marker TGF- $\beta 1$ in cardiac macrophages [53]. TGF $\beta 1$ is upregulated in various experimental models of cardiac hypertrophy [54], and functional blockade of TGF $\beta 1$ prevents cardiac interstitial fibrosis induced by pressure overload in rats [55]. However, TGF $\beta 1$ upregulates the expression of NADPH oxidase and induces further ROS generation [42]. $\mathrm{Hu}$ and colleagues suggested positive feedback between TGF $\beta 1$, NADPH oxidase-mediated ROS generation, and LOX-1 [56]. Among numerous fibrotic signals, TGF $\beta 1$ is reported to be a key fibrogenic mediator. Smad2 and Smad3 are well-documented downstream mediators of TGF $\beta 1$-induced fibrosis, and activations of Smad2 and Smad3 are known to stimulate matrix-component synthesis, such as collagens [13]. TGF- $\beta 1$ activates Smad-mediated signaling pathways on 
binding to TGF- $\beta$ receptors on cardiomyocytes and cardiac fibroblasts [57]. In our study, Smad3 was activated in both 4-week-old and 10-month-old mice after $\mathrm{PM}_{2.5}$ exposure. This finding implied that $\mathrm{PM}_{2.5}$ induced cardiac fibrosis might involve the TGF $\beta 1$-Smad pathway.

Many studies have documented that $\mathrm{Zn}$ and $\mathrm{Mn}$ can enter systemic circulation and lead to lung fibrosis and cardiovascular disease [58-60]. In our latest study, we found that $\mathrm{PM}_{2.5}$-bound metals could reach and deposit in the heart with a developmental window-dependent property. The content of $\mathrm{Zn}$ increased significantly in hearts of 4-week-old and 10-month-old mice. The contents of $\mathrm{Mn}$ and $\mathrm{Cd}$ increased significantly in hearts of 10-month-old mice [61]. It is speculated that heavy metals, such as $\mathrm{Zn}, \mathrm{Mn}$, and $\mathrm{Cd}$, might be responsible for $\mathrm{PM}_{2.5}$ induced cardiac toxicity. However, further experiments are needed to confirm the hypothesis.

There are several limitations to our study. The first limitation is the exposure method. Although oropharyngeal aspiration has been commonly used for experimental PM exposure [62-64]. Because it delivers a bolus high dose of particles to the lung, rather than repeated inhalation at lower doses, it may produce different effects in the lungs and hearts compare with exposure by inhalation. An additional limitation pertains to the low sensitivity of the tail-cuff method used to assay heart rate and blood pressure in this study. It is reported that tail-cuff readings are on average $39 \mathrm{mmHg}$ lower than telemetric measurements for systolic blood pressure [65]. We exerted considerable care in the measurements with careful training of the mice. The data of each animal were measured as the mean of at least 5 successful measurements.

\section{Conclusion}

In this report, we provide evidence that $\mathrm{PM}_{2.5}$ exposure induced cardiac dysfunction in mice at all ages tested, elevated heart rate and blood pressure in 10-month-old mice, and caused cardiac fibrosis in 10-month-old and 4-week-old mice. In combination, these data provide strong evidence that exposure to $\mathrm{PM}_{2.5}$ has significant effects on juveniles and the elderly because they are more susceptible to cardiovascular disease. Furthermore, all the above adverse effects in 10-month-old and 4-week-old mice could be restored after withdrawal $\mathrm{PM}_{2.5}$ exposure for 2 weeks. The mechanisms by which $\mathrm{PM}_{2.5}$ exposure resulted in cardiac lesions might involve the generation of oxidative stress and inflammation in lungs and the activation of TGF $\beta 1$-Smad pathway.

\section{Methods}

Collection of $\mathrm{PM}_{2.5}$ samples

Sampling was performed between 2012 and 2013 in Taiyuan, Northern China. The $\mathrm{PM}_{2.5}$ samples were
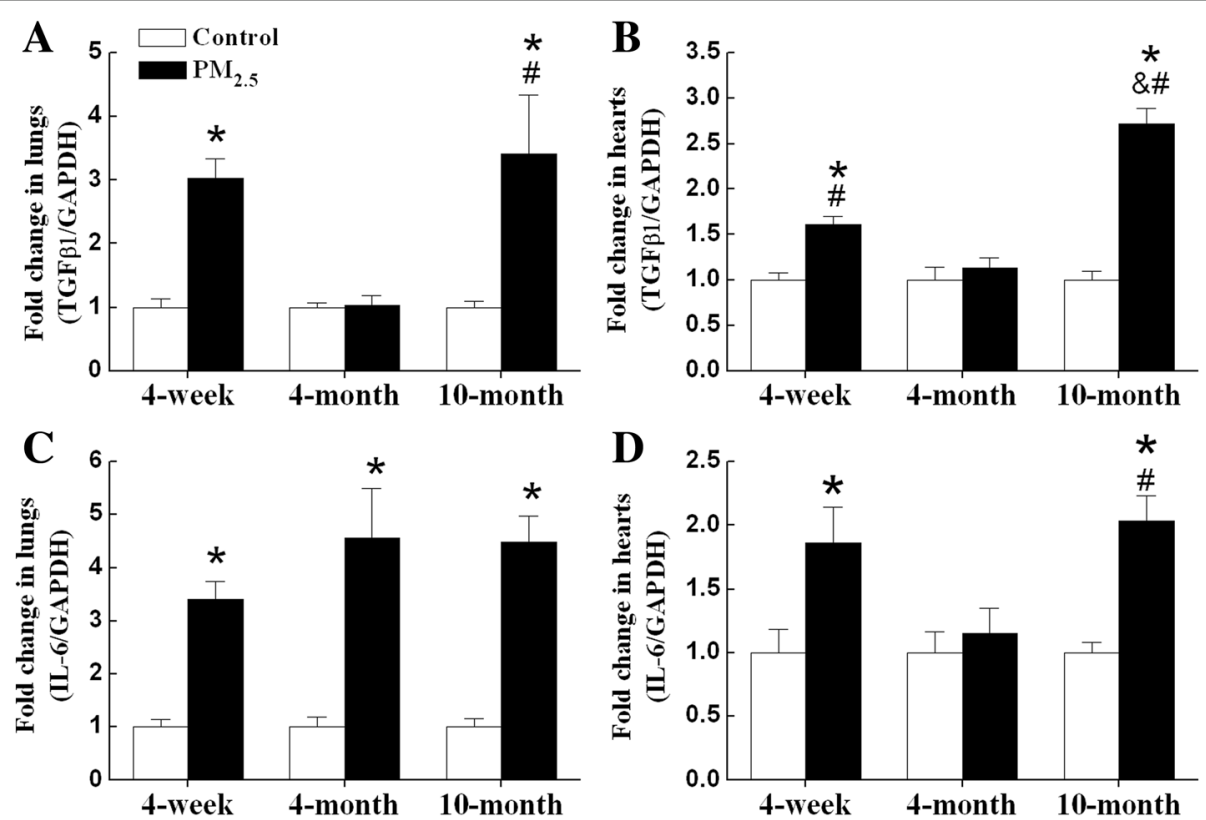

Fig. $6 \mathrm{PM}_{2.5}$ induces mRNA expression of TGF $\beta 1$ and IL-6 in lungs and hearts of mice. mRNA expression of TGF $\beta 1$ and IL-6 in lungs (a, c) and hearts $(\mathbf{b}, \mathbf{d})$ were detected by qPCR. GAPDH was used as the internal control. The mean expression in each treated group was shown as a fold change compared to the mean expression in each control group, which had been calculated as target gene /GAPDH and ascribed an arbitrary value of 1 . Each column and bar represents the mean \pm SE $(n=6-9)$. TGF $\beta 1$, transforming growth factor $\beta 1 ;$; IL-6, interleukin-6. ${ }^{*} P<0.05$ vs. age-matched control by two-way ANOVA and Turkey's post hoc tests; \& $P<0.05$ vs. 4-week-old $P M_{2.5}$ group; \# $P<0.05$ vs. 4-month-old $\mathrm{PM}_{2.5}$ group by two-way ANOVA and Bonferroni's post hoc tests 


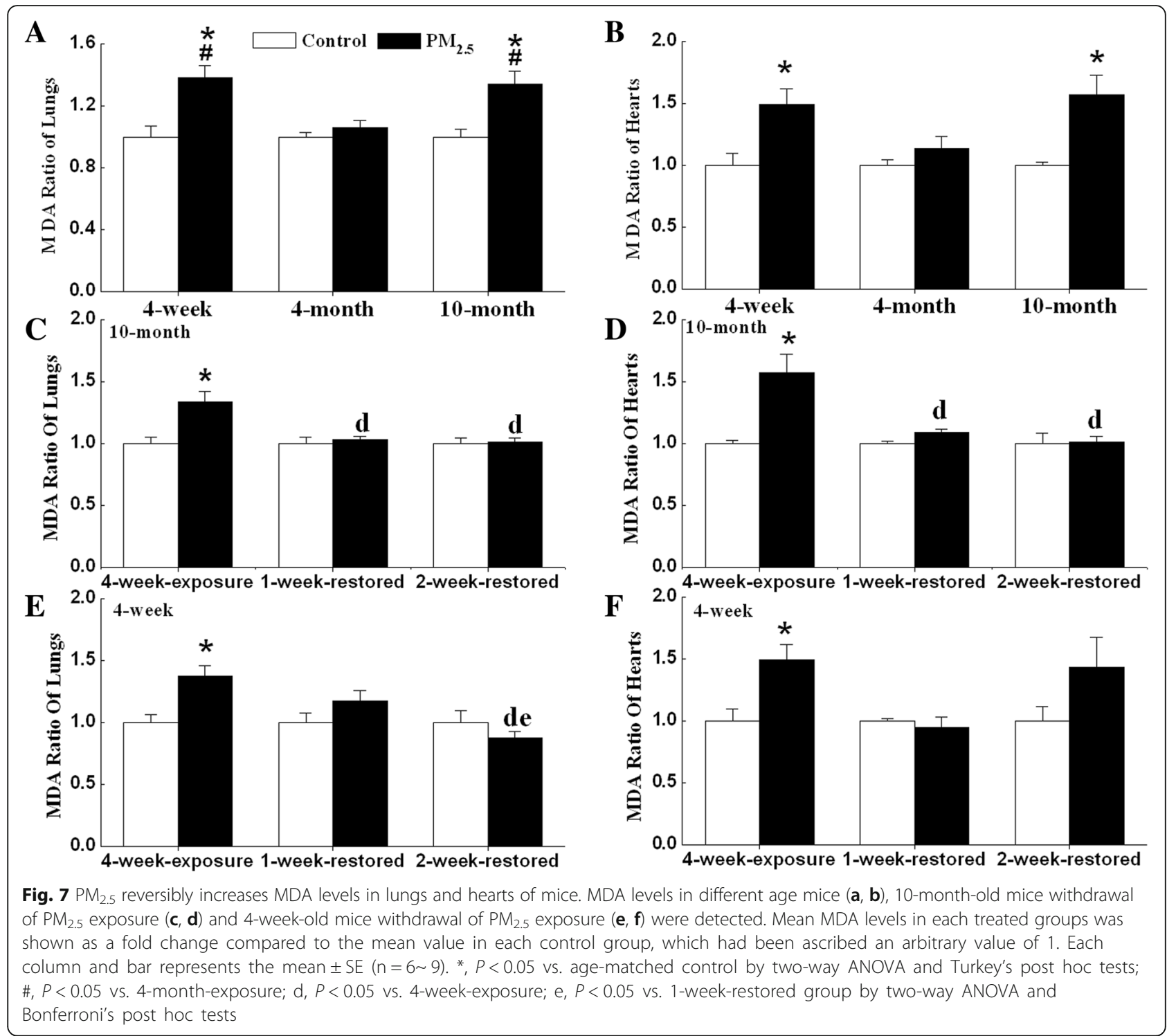

collected onto quartz filters ( $\Phi 90 \mathrm{~mm}$, Munktell, Falun, Dalarna, Sweden) with PM middle-volume air samplers (TH-150CIII, Wuhan, China). Details of sample collection and components analysis of $\mathrm{PM}_{2.5}$ have been previously described [66] and provided in Additional file 3: Table S1-Table S4 in Supporting information.

\section{Animals and exposure}

Female C57BL/6 mice were purchased from the Junke Biological Engineering Co., LTD (Nanjing, China). Animals were housed in individual stainless steel cages under standard conditions $\left(24 \pm 2{ }^{\circ} \mathrm{C}\right.$ and $50 \pm 5 \%$ humidity) with a $12 \mathrm{~h}$ light-dark cycle in SPF conditions. The protocol of animal procedures was conducted in accordance with the National Institutes of Health Guide for the Care and Use of Laboratory Animals and was approved by the Institutional Animal Care and Use Committee of Shanxi University.

In study-1, C57BL/6 mice at 4 weeks, 4 months and 10 months were randomized into two subgroups. The mice received oropharyngeal aspiration of $0.9 \%$ saline (control groups) or $3 \mathrm{mg} / \mathrm{kg}$. b.w. $\mathrm{PM}_{2.5}$ suspension ( $3 \mathrm{mg} / \mathrm{ml}, \mathrm{PM}_{2.5}$ groups) $15-30 \mu \mathrm{l}$ depend on the body weight of each animal every other day for 4 weeks. When not being treated, the mice had free access to standard food and water. Mice were sacrificed $24 \mathrm{~h}$ after the final exposure.

In study-2, C57BL/6 mice at 4-week-old or 10-monthold were received oropharyngeal aspiration of $0.9 \%$ saline (controls) or $3 \mathrm{mg} / \mathrm{kg}$. b.w. $\mathrm{PM}_{2.5}$ suspension $\left(\mathrm{PM}_{2.5}\right.$ groups) every other day for 4 weeks. Mice were sacrificed $24 \mathrm{~h}, 1$ week, or 2 weeks after the final exposure, respectively. The hearts and lungs were removed, and all 

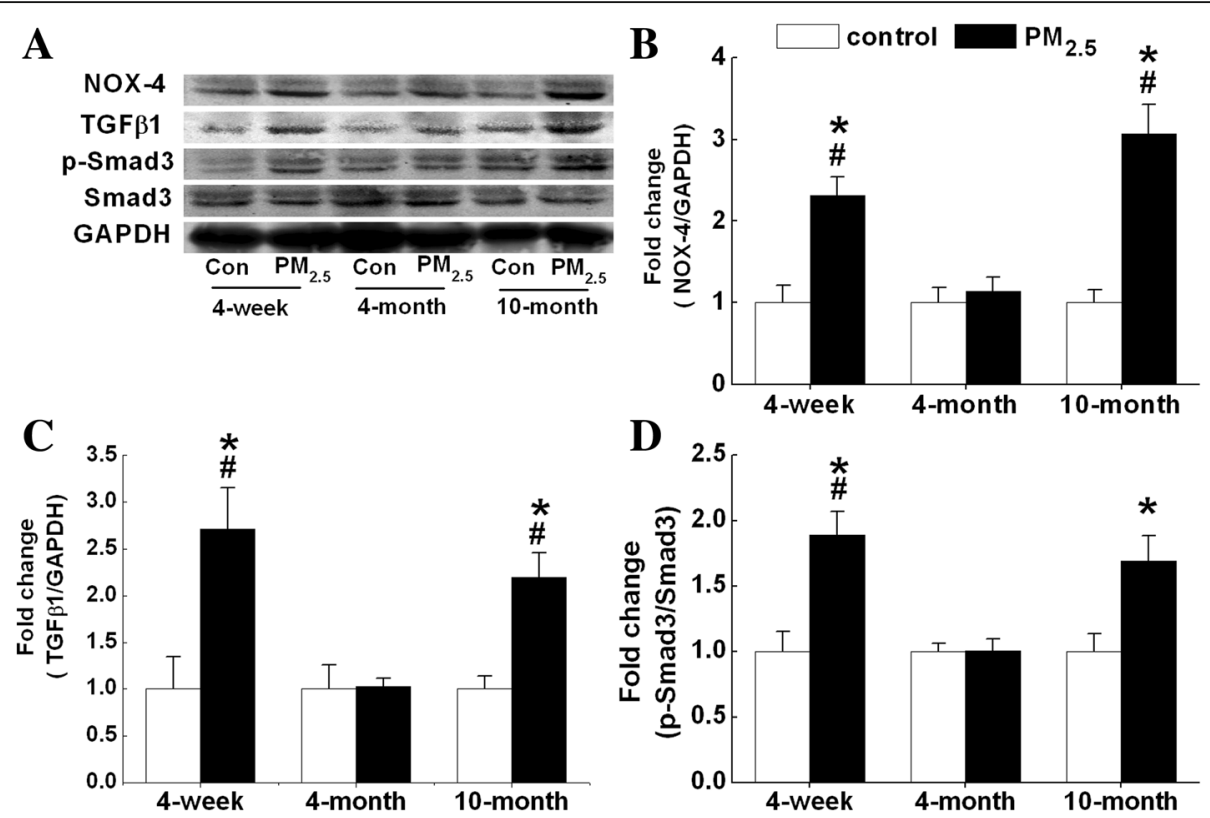

Fig. $8 \mathrm{PM}_{2.5}$-induced cardiac fibrosis is associated with NOX4-TGFß1-Smad signaling. Protein levels were measured by Western blot. (a), Representative Western blot results of each protein. The protein levels of NOX-4 (b), TGF 1 1 (c), and ratio of p-Smad3 and Smad 3 (d). Each column and bar represents the mean \pm SE $(n=3 \sim 6)$. The mean expression in each treated group was shown as a fold change compared to the mean expression in each control group, which had been calculated as target protein /GAPDH and ascribed an arbitrary value of 1. NOX-4, NADPH oxidase 4; TGF $\beta 1$, transforming growth factor $\beta 1$. *, $P<0.05$ vs. age-matched control by two-way ANOVA and Turkey's post hoc tests; \#, $P<0.05$ vs. 4-month-exposure by two-way ANOVA and Bonferroni's post hoc tests

samples were fixed or quick frozen in liquid nitrogen and stored at $-80^{\circ} \mathrm{C}$.

\section{Heart rate and blood pressure assay}

Heart rate and blood pressure were measured using a standard tail-cuff system (BP-2010A System, Softron). The blood pressure and heart rate data of each mice were measured as the mean of at least 5 successful measurements.

\section{Echocardiographic assessment}

Heart function and structure were assessed by echocardiography using a Vevo $770^{\text {mix }}$ ultrasound system (VisualSonics, Toronto, Ontario, Canada), which included a $21-\mathrm{MHz}$ transducer. Mice were anesthetized with $2 \%$ isoflurane administered via a nose cone, were shaved from the chest, and were placed in the supine position on a hotplate. Echocardiography and off-line data analysis was performed by a single observer. The observer was blinded as to the age and group of mice being analyzed. Two-dimensional (2D) and M-mode echocardiography images were obtained from the parasternal region and viewed to measure left ventricular end-diastolic dimension (LVEDD), left ventricular end-systolic dimension (LVESD), posterior wall thickness in diastole (LVPWd), left ventricular end diastolic volume (LVEDV), and left ventricular end systolic volume (LVESV). Left ventricle filling parameters were assessed from the ends of mitral leaflets in apical quadrilocular image, and peak early $(E)$ and after (A) diastolic flow velocities were measured. Tissue Doppler assessment was conducted on apical quadrilocular image. Peak early motion (E') and peak after motion $\left(A^{\prime}\right)$ wave values were measured. Ejection fraction (EF), fractional shortening (FS), E/A ratio, E'/A' ratio, and E/E' ratio were obtained using defined calculations. Each parameter was measured in at least 3 cycles, and mean figures were utilized. All measurements were performed offline using the Vevo $770^{\text {mix }}$ system software (VisualSonics, Toronto, Ontario, Canada).

\section{Histological analysis by Masson's trichrome staining}

The cardiac tissue from mice of each group was rapidly removed, washed several times with $0.1 \mu \mathrm{M}$ phosphate buffered saline (PBS, pH 7.4), fixed in 10\% formalin for $24 \mathrm{~h}$ at room temperature, dehydrated by graded ethanol, and embedded in paraffin. Sections (5-6 $\mu$ m-thick) were deparaffinized with xylene, stained with Masson's trichrome staining, and observed by microscopy. Quantitative planimetric analyses were performed on three successive sections per slide, and at least 7 sections from 3 consecutive slides per mouse were examined. Each image was digitized using a digital camera and analyzed under a research microscope (Olympus, Japan) using Image-Pro Plus software (version 5.0). The left 
ventricular cross-section collagen accumulation was quantified by the ratio of blue area to total myocardium area. All analyses were performed by an investigator blinded to the group assignments.

\section{ROS detection}

Fresh hearts were used to prepare a 10\% $(w / v)$ PBS homogenate. After centrifuging at $1000 \mathrm{~g}$ for $10 \mathrm{~min}$ at $4{ }^{\circ} \mathrm{C}$, the supernatant was collected and used to evaluate reactive oxygen species (ROS) and protein content. In 96-well plates, $190 \mu \mathrm{L}$ of the supernatant and $10 \mu \mathrm{L}$ of $1 \mathrm{mM}$ DCFHDA were added to each well. After incubating at $37^{\circ} \mathrm{C}$ for $30 \mathrm{~min}$ in the dark, the fluorescence was read at $485 \mathrm{~nm}$ for excitation and $530 \mathrm{~nm}$ for emission with a fluorescent plate reader (Varioskan Flash, Thermo Scientific, America). The results were calculated as the fluorescence units $(\mathrm{FLU}) / \mathrm{mg}$ protein. The value of the 4-week-old mice in control group was set to 1 .

\section{Oxidative stress analysis}

The heart or lung tissues were homogenized and centrifuged, and the supernatants were collected for biomarker and protein concentration determination. The level of the lipid peroxidation product malondialdehyde (MDA) was measured using commercial kits (Nanjing Jiancheng Bioengineering Institute, Nanjing, China).

\section{Quantitative real-time PCR}

Total RNA was isolated using TRIzol Reagent (TaKaRa, Dalian, China) according to the manufacturer's instructions. Total RNA was then treated with DNase I (TaKaRa, Dalian, China), and cDNA was synthesized using a First Strand cDNA Synthesis kit (TaKaRa, Dalian, China) The cDNA product was stored at $-80{ }^{\circ} \mathrm{C}$ until used.

Real-time quantitative PCR (qPCR) was performed using an IQ5 Real-Time PCR System (Bio-Rad, USA) and SYBR Green qPCR Master Mix kit (Takara, Dalian, China). The primers are listed in Additional file 3: Table S5. The cycling conditions were as follows: $3 \mathrm{~min}$ at $95^{\circ}$ $\mathrm{C}, 40$ cycles of $20 \mathrm{~s}$ at $94{ }^{\circ} \mathrm{C}, 20 \mathrm{~s}$ at $55-60{ }^{\circ} \mathrm{C}$, and $20 \mathrm{~s}$ at $72{ }^{\circ} \mathrm{C}$. The threshold cycle $(\mathrm{Ct})$ values for the experimental samples were plotted onto the dilution series standard curve. The target quantities were calculated from separate standard curves generated for each experiment. The relative expression values were then determined by dividing the quantities of the target sequence of interest with the quantity obtained for GAPDH as an internal reference gene. The qPCR was repeated three times for each gene.

\section{Western blot analysis}

Proteins were extracted in ice-cold lysis buffer (1\% Nonidet P-40, $1 \mathrm{mM}$ EDTA, $125 \mathrm{mM}$ sodium fluoride,
$0.5 \mathrm{mM}$ sodium vanadate, $2.5 \mu \mathrm{g} / \mathrm{mL}$ of aprotinin, $5 \mu \mathrm{g} /$ $\mathrm{mL}$ of pepstatin, $50 \mu \mathrm{g} / \mathrm{mL}$ of leupeptin, $25 \mu \mathrm{M}$ PMSF, and $25 \mu \mathrm{g} / \mathrm{mL}$ of trypsin inhibitor). The protein concentration was determined according to the Bradford method using BSA as the standard protein [67]. Sodium dodecyl sulfate-polyacrylamide gel electrophoresis was performed on $50 \mu \mathrm{g}$ protein samples using $12 \%$ resolving $/ 4 \%$ stacking Tris- $\mathrm{HCl}$ gels. Electrophoresis proteins were transferred to nitrocellulose membranes using Bio-Rad Mini Trans-Blot Electrophoretic Transfer Cell Instruments. Membranes were blocked in 3\% BSA solution for $1 \mathrm{~h}$ at room temperature and incubated overnight at $4{ }^{\circ} \mathrm{C}$ with antibodies to targeted proteins (anti-GAPDH antibody, CST; anti-Colla1 antibody, Bioss; anti-Col3a1 antibody, Bioss; anti-TGF $\beta 1$ antibody, Proteintech; anti- NADPH oxidase 4 (NOX-4)antibody, BBI; anti-Smad 3 antibody, BBI; and anti-P-Smad 3 antibody, BBI). After washing, the membranes were incubated with fluorescently labeled secondary antibody $(1,5000)$ (IRDye $800 \mathrm{CW}$ goat anti-rabbit IgG $(\mathrm{H}+\mathrm{L})$, LI-COR), scanned, and detected with the LI-COR Odyssey Infrared Fluorescent System.

\section{Statistical analysis}

All data are expressed as the means \pm standard error of the mean (SE). Comparison between groups in Fig. 1a and b was conducted using two-way repeated analysis of variance (ANOVA) followed by Tukey's post-test within each $\mathrm{x}$-axis time-point across all groups or Tukey's post-test within each treatment group across $\mathrm{x}$-axis time-points. Two-way non-repeated ANOVA followed by Tukey's post-test within each group across the $\mathrm{x}$-axis time-points or Bonferroni's post-test within each $\mathrm{x}$-axis time-point across the control and $\mathrm{PM}_{2.5}$ groups were used to compare between groups in others figures. Differences for all tests were considered significant when $P<0.05$.

\section{Additional files}

\begin{abstract}
Additional file 1: Figure S1. $\mathrm{PM}_{2.5}$ induces collagen mRNA (A) and protein (B) expression in H9C2 cells. (A) mRNA expressions of Col1a1 and Col3a1 in H9C2 cells were detected by qPCR. (B) The protein levels of Col1a1 and Col3a1 were detected by Western blot. GAPDH was used as the internal control. The mean expression in four seasons $\mathrm{PM}_{2.5}$ treated group was shown as a fold change compared to the mean expression of control group, which had been calculated as target gene or protein /GAPDH and ascribed an arbitrary value of 1. Each column and bar represents the mean $\pm S E(n=3)$. Significantly different from control by one-way ANOVA with Tukey's post-test. ${ }^{*} P<0.05$ vs. control group; a $\mathrm{P}<0.05$ vs. spring $\mathrm{PM}_{2.5}$ group; $\mathrm{b} \mathrm{P}<0.05$ vs. summer $\mathrm{PM}_{2.5}$ group; $\mathrm{C}$ $\mathrm{P}<0.05$ vs. autumn $\mathrm{PM}_{2.5}$ group. (TIF $440 \mathrm{~kb}$ )
\end{abstract}

Additional file 2: Figure S2. Estrogen levels in plasma of different age mice. Each column and bar represents the mean $\pm S E(n=6)$. \# $P<0.05$ vs. 4-week-exposure by two-way ANOVA and Bonferroni's post hoc tests. (TIF $106 \mathrm{~kb}$ )

Additional file 3: Table S1. Contents of inorganic ion in $\mathrm{PM}_{2.5}$ samples from different seasons (unit: $\mu \mathrm{g} / \mathrm{m}^{3}$ ). Table S2. Element contents in $\mathrm{PM}_{2.5}$ 
samples from different seasons (unit: $\mathrm{ng} / \mathrm{m}^{3}$ ). Table $\mathbf{S 3}$. Contents of polycyclic aromatic hydrocarbons (PAHs) in PM $_{2.5}$ samples from different seasons (unit: $\mathrm{ng} / \mathrm{m}^{3}$ ). Table S4. Carbon contents in $\mathrm{PM}_{2.5}$ samples from different seasons (unit: $\mu \mathrm{g} / \mathrm{m}^{3}$ ). Table S5. Sequences of primers used in real-time PCR. (DOCX $35 \mathrm{~kb})$

\section{Abbreviations}

ANOVA: Analysis of variance; bpm: Beats per minute; cDNA: Complimentary deoxyribonucleic acid; Col1a1: Collagen I; Col3a1: Collagen III; DCFHDA: 2',7' dichlorodihydro fluorescein diacetate; DMEM: Dulbecco's modified eagle's medium; E/E': Ratio of peak early diastolic flow velocities and peak early motion wave values; EF: Ejection fraction; GAPDH: Glyceraldehye 3phosphatede hydrogenase; IL-6: Interleukin 6; LPS: Lipopolysaccharide; LV: Left ventricle; mRNA: Messenger ribonucleic acid; NOX-4: NADPH oxidase subunit 4; PM: Particulate matter; $\mathrm{PM}_{2.5}$ : Particulate matter with a diameter of $2.5 \mu \mathrm{m}$ or less; qRT-PCR: Quantitative real time polymerase chain reaction; ROS: Reactive oxygen species; TGF $\beta 1$ : Transforming growth factor $\beta 1$

\section{Acknowledgements}

The authors thank Hao Li for the heart function assessment and data analysis using ultrasound (from Fuwai Hospital, National Center for Cardiovascular Diseases, China).

\section{Funding}

This research was supported by the National Natural Science Foundation of China(21777091, 91543203, 21377076, 91543206, 11435002, 21222701), Research Project for Young Sanjin Scholarship of Shanxi, Program for the Outstanding Innovative Teams of Higher Learning Institutions of Shanxi, State Key Laboratory of Environmental Chemistry and Ecotoxicology, Research Center for Eco-Environmental Sciences, Chinese Academy of Sciences (KF2016-17), Research Project Supported by Shanxi Scholarship Council of China (015-006).

\section{Availability of data and materials}

The datasets during and/or analysed during the current study available from the corresponding author on reasonable request.

\section{Authors' contributions}

$\mathrm{GQ}$, contributed to generating hypothesis and experimental design, conducted experiments, interpreted data, wrote the manuscript and is the primary author of the manuscript; JX, performed heart rate and blood pressure assay, H9C2 cell culture, ROS assay, GRT-PCR and Western experiments, contributed to preparation of figures; $Y Z$, performed $\mathrm{PM}_{25}$ collection and animal exposure; LG, contributed to supervising the entire project; RC, contributed to manuscript preparation. NS, contributed to supervising the entire project and was responsible for overall coordination of the project. All authors read and approved the final manuscript.

\section{Ethics approval and consent to participate}

All animal procedures were conducted in accordance with the National Institutes of Health Guide for the Care and Use of Laboratory Animals and were approved by the Institutional Animal Care and Use Committee of Shanxi University.

\section{Consent for publication}

Not applicable.

\section{Competing interests}

The authors declare that they have no competing interests.

\section{Publisher's Note}

Springer Nature remains neutral with regard to jurisdictional claims in published maps and institutional affiliations.

\section{Author details}

'College of Environment and Resource, Research Center of Environment and Health, Shanxi University, Taiyuan, Shanxi 030006, People's Republic of China. ${ }^{2}$ State Key Laboratory of Environmental Chemistry and Ecotoxicology, Research Center for Eco-Environmental Sciences, Chinese Academy of Sciences, Beijing 100085, People's Republic of China. ${ }^{3}$ CAS Key Laboratory for
Biomedical Effects of Nanomaterials and Nanosafety\& CAS Center for Excellence in Nanoscience, Beijing Key Laboratory of Ambient Particles Health Effects and PreventionTechniques, National Center for Nanoscience \& Technology of China, Beijing 100190, People's Republic of China.

Received: 21 November 2017 Accepted: 14 June 2018

Published online: 25 June 2018

\section{References}

1. Lelieveld J, Evans JS, Fnais M, Giannadaki D, Pozzer A. The contribution of outdoor air pollution sources to premature mortality on a global scale. Nature. 2015;525:367-71

2. Brook RD, Franklin B, Cascio W, Hong Y, Howard G, Lipsett M, Luepker R, Mittleman M, Samet J, Smith SC. Air pollution and cardiovascular disease: a statement for healthcare professionals from the expert panel on population and prevention science of the american heart association. Circulation. 2004; 109:2655-71.

3. Shah AS, Langrish JP, Nair H, Mcallister DA, Hunter AL, Donaldson K, Newby DE, Mills NL. Global association of air pollution and heart failure: a systematic review and meta-analysis. Lancet. 2013;382:1039.

4. Bell ML, Ebisu K, Peng RD, Walker J, Samet JM, Zeger SL, Dominici F. Seasonal and regional short-term effects of fine particles on hospital admissions in 202 us counties, 1999-2005. Am J Epidemiol. 2008;168:1301-10.

5. Brook RD, Rajagopalan S, Pope CA, Brook JR, Bhatnagar A, Diezroux AV, Holguin F, Hong Y, Luepker RV, Mittleman MA. Particulate matter air pollution and cardiovascular disease. Circulation. 2010;121:2331-78.

6. Lee BJ, Kim B, Lee K. Air pollution exposure and cardiovascular disease. Toxicol Res. 2014:30:71.

7. Wold LE, Ying Z, Hutchinson KR, Velten M, Gorr MW, Velten C, Youtz DJ, Wang A, Lucchesi PA, Sun Q. Cardiovascular remodeling in response to long-term exposure to fine particulate matter air pollution. Circ Heart Failure. 2012;5:452

8. Ying Z, Yue PX, Zhong M, Sun Q, Mikolaj M, Wang A, Brook RD, Chen LC, Rajagopalan S. Air pollution and cardiac remodeling: a role for rhoa/rhokinase. Am J Physiol Heart Circ Physiol. 2009;296:H1540.

9. Tankersley CG, Champion HC, Takimoto E, Gabrielson K, Bedja D, Misra V, Elhaddad H, Rabold R, Mitzner W. Exposure to inhaled particulate matter impairs cardiac function in senescent mice. Ajp Regul Integr Comp Physiol. 2008:295:R252-63.

10. Gorr MW, Velten M, Nelin TD, Youtz DJ, Sun Q, Wold LE. Early life exposure to air pollution induces adult cardiac dysfunction. Am J Physiol Heart Circ Physiol. 2014;307:1353-60.

11. Weldy CS, Liu Y, Chang YC, Medvedev IO, Fox JR, Larson TV, Chien WM, Chin MT. In utero and early life exposure to diesel exhaust air pollution increases adult susceptibility to heart failure in mice. Part Fibre Toxicol. 2013;10:59.

12. Newby DE, Mannucci PM, Tell GS, Baccarelli AA, Brook RD, Donaldson K, Forastiere F, Franchini M, Franco OH, Graham I. Expert position paper on air pollution and cardiovascular disease. Eur Heart J. 2015;36:83.

13. Biernacka A, Dobaczewski M, Frangogiannis NG. Tgf- $\beta$ signaling in fibrosis Growth Factors. 2011;29:196-202

14. Fares A. Winter cardiovascular diseases phenomenon. N Am J Med Sci. 2013;5:266-79.

15. Hsu WH, Hwang SA, Kinney PL, Lin S. Seasonal and temperature modifications of the association between fine particulate air pollution and cardiovascular hospitalization in New York state. Sci Total Environ. 2017:578: 626-32.

16. Gurkan OU, O'Donnell C, Brower R, Ruckdeschel E, Becker PM. Differential effects of mechanical ventilatory strategy on lung injury and systemic organ inflammation in mice. Am J Physiol Lung Cell Mol Physiol. 2003;285:710-8.

17. Yin W, Hou J, Xu T, Cheng J, Wang X, Jiao S, Wang L, Huang C, Zhang Y, Yuan J. Association of individual-level concentrations and human respiratory tract deposited doses of fine particulate matter with alternation in blood pressure. Environ Pollut. 2017;230:621

18. Guo S, Hu M, Zamora ML, Peng J, Shang D, Zheng J, Du Z, Wu Z, Shao M, Zeng L. Elucidating severe urban haze formation in China. Proc Natl Acad Sci U S A. 2014:111:17373.

19. Li RJ, Kou XJ, Geng H, Dong C, Cai ZW. Pollution characteristics of ambient pm 2.5 -bound pahs and npahs in a typical winter time period in Taiyuan. Chin Chem Lett. 2014;25:663-6. 
20. Cao LX, Geng H, Yao CT, Zhao L, Duan PL, Xuan YY, Li H. Investigation of chemical compositions of atmospheric fine particles during a wintertime haze episode in Taiyuan city. China Environ Sci. 2014;34:837-43.

21. 3Rd PCA. Epidemiology of fine particulate air pollution and human health: biologic mechanisms and who's at risk? Environ Health Perspect. 2000;108: 713-23.

22. Gold DR, Litonjua AA, Zanobetti A, Coull BA, Schwartz J, Maccallum G, Verrier RL, Nearing BD, Canner MJ, Suh H. Air pollution and st-segment depression in elderly subjects. Environ Health Perspect. 2005;113:883-7.

23. Liang R, Zhang B, Zhao X, Ruan Y, Lian H, Fan Z. Effect of exposure to pm2. 5 on blood pressure: a systematic review and meta-analysis. J Hypertens. 2014;32:2130-41.

24. Wu S, Deng F, Huang J, Wang H, Shima M, Wang X, Qin Y, Zheng C, Wei H, Hao Y. Blood pressure changes and chemical constituents of particulate air pollution: results from the healthy volunteer natural relocation (hvnr) study. Environ Health Perspect. 2013;121:66-72.

25. Kamal AS, Rohr AC, Mukherjee B, Morishita M, Keeler GJ, Harkema JR, Wagner JG. Pm2.5-induced changes in cardiac function of hypertensive rats depend on wind direction and specific sources in Steubenville, Ohio. Inhal Toxicol. 2011;23:417-30.

26. Ying Z, Xie X, Bai $Y$, Chen $M$, Wang $X$, Zhang X, Morishita $M$, Sun $Q$, Rajagopalan $S$. Exposure to concentrated ambient particulate matter induces reversible increase of heart weight in spontaneously hypertensive rats. Part Fibre Toxicol. 2015;12:15

27. Liu Y, Wei-Ming C, Medvedev IO, Weldy CS, Luchtel DL, Rosenfeld ME, Chin MT. Inhalation of diesel exhaust does not exacerbate cardiac hypertrophy or heart failure in two mouse models of cardiac hypertrophy. Part Fibre Toxicol. 2013;10:49

28. Carter JD, Madamanchi NR, Stouffer GA, Runge MS, Cascio WE, Tong $H$. Ultrafine particulate matter exposure impairs vasorelaxant response in superoxide dismutase 2-deficient murine aortic rings. J Toxicol Environ Health A. 2017:81:1-10.

29. Pei Y, Jiang R, Zou Y, Yu W, Zhang S, Wang G, Zhao J, Song W. Effects of fine particulate matter (pm2.5) on systemic oxidative stress and cardiac function in apoe-/- mice. Int J Environ Res Public Health. 2016;13:484.

30. Jr HR, Cm A, Sa W, Bj G, Pr K, Dw B, Ke Y. Mouse heart valve structure and function: echocardiographic and morphometric analyses from the fetus through the aged adult. Am J Physiol. 2008:294:2480-8.

31. Keller KM, Howlett SE. Sex differences in the biology and pathology of the aging heart. Can J Cardiol. 2016;32:1065-73.

32. Ying Z, Xu X, Bai Y, Zhong J, Chen M, Liang Y, Zhao J, Liu D, Morishita M, Sun Q. Long-term exposure to concentrated ambient pm2.5 increases mouse blood pressure through abnormal activation of the sympathetic nervous system: a role for hypothalamic inflammation. Environ Health Perspect. 2014;122:79.

33. Kasner M, Westermann D, Steendijk P, Gaub R, Wilkenshoff U, Weitmann K Hoffmann W, Poller W, Schultheiss HP, Pauschinger M. Utility of doppler echocardiography and tissue doppler imaging in the estimation of diastolic function in heart failure with normal ejection fraction: a comparative doppler-conductance catheterization study. Circulation. 2007;116:637-47.

34. Lu X, Ye Z, Zheng S, Ren H, Zeng J, Wang X, Jose PA, Chen K, Zeng C. Long-term exposure of fine particulate matter causes hypertension by impaired renal d1 receptor-mediated sodium excretion via upregulation of g-protein-coupled receptor kinase type 4 expression in sprague-dawley rats. Journal of the American Heart Association Cardiovascular \& Cerebrovascular Disease. 2018;7. https://doi.org/10.1161/JAHA.117.007185

35. Sancini G, Farina F, Battaglia C, Cifola I, Mangano E, Mantecca P, Camatini M, Palestini P. Health risk assessment for air pollutants: alterations in lung and cardiac gene expression in mice exposed to Milano winter fine particulate matter (pm2.5). PLoS One. 2014;9:e109685.

36. Jia-Ping W, Dennis Jine-Yuan H, Wei-Wen K, Chien-Kuo H, Peiying P, Yu-Lan Y, Chien-Chung L, V Vijaya P, Cecilia Hsuan D, Chih-Yang H. Secondhand smoke exposure reduced the compensatory effects of igf-i growth signaling in the aging rat hearts. Int J Med Sci. 2015;12:708-18.

37. Li F, Lang F, Zhang H, Xu L, Wang Y, Hao E. Role of tfeb mediated autophagy, oxidative stress, inflammation, and cell death in endotoxin induced myocardial toxicity of young and aged mice. Oxidative Med Cell Longev. 2016:2016:5380319. https://doi.org/10.1155/2016/5380319.

38. Hua Y, Zhang Y, Ceylanisik AF, Wold LE, Nunn JM, Ren J. Chronic akt activation accentuates aging-induced cardiac hypertrophy and myocardial contractile dysfunction: role of autophagy. Basic Res Cardiol. 2011;106:1173-91.
39. Yang X, Sreejayan N, Ren J. Views from within and beyond: narratives of cardiac contractile dysfunction under senescence. Endocrine. 2005:26:127-37.

40. Vitale C, Mendelsohn ME, Rosano GM. Gender differences in the cardiovascular effect of sex hormones. Fundam Clin Pharmacol. 2009;6:675-85.

41. Xue B, Zhang Z, Beltz TG, Guo F, Hay M, Johnson AK. Estrogen regulation of the brain renin-angiotensin system in protection against angiotensin iiinduced sensitization of hypertension. Am J Physiol Heart Circ Physiol. 2014; 307:H191.

42. Cucoranu I, Clempus R, Dikalova A, Phelan PJ, Ariyan S, Dikalov S, Dan S. Nad(p)h oxidase 4 mediates transforming growth factor- $\beta 1$-induced differentiation of cardiac fibroblasts into myofibroblasts. Circ Res. 2005;97:900-7.

43. Tirziu D, Giordano FJ, Simons M. Cell communications in the heart. Circulation. 2010;122:928-37.

44. Zhang M, Shah AM. Ros signalling between endothelial cells and cardiac cells. Cardiovasc Res. 2014:102:249-57.

45. Zhang Y, Ji X, Ku T, Li G, Sang N. Heavy metals bound to fine particulate matter from northern China induce season-dependent health risks: a study based on myocardial toxicity. Environ Pollut. 2016;216:380.

46. Fiordelisi A, Piscitelli P, Trimarco B, Coscioni E, laccarino G, Sorriento D. The mechanisms of air pollution and particulate matter in cardiovascular diseases. Heart Fail Rev. 2017:22:1-11.

47. Ganguly K, Ettehadieh D, Upadhyay S, Takenaka S, Adler T, Karg E, Krombach F, Kreyling WG, Schulz H, Schmid O. Early pulmonary response is critical for extra-pulmonary carbon nanoparticle mediated effects: comparison of inhalation versus intra-arterial infusion exposures in mice. Part Fibre Toxicol. 2017;14:19.

48. Zuo L, Youtz DJ, Wold LE. Particulate matter exposure exacerbates high glucose-induced cardiomyocyte dysfunction through ros generation. PLoS One. 2011;6:e23116

49. Cave AC, Brewer AC, Narayanapanicker A, Ray R, Grieve DJ, Walker S, Shah AM. Nadph oxidases in cardiovascular health and disease. Antioxid Redox Signal. 2006:8:691.

50. Privratsky JR, Wold LE, Sowers JR, Quinn MT, Ren J. At1 blockade prevents glucose-induced cardiac dysfunction in ventricular myocytes: role of the at 1 receptor and nadph oxidase. Hypertension. 2003;42:206-12.

51. Li PF, Dietz R, Von HR. Superoxide induces apoptosis in cardiomyocytes, but proliferation and expression of transforming growth factor-beta1 in cardiac fibroblasts. FEBS Lett. 1999:448:206-10.

52. Kamo T, Akazawa H, Komuro I. Cardiac nonmyocytes in the hub of cardiac hypertrophy. Circ Res. 2015:117:89.

53. Shen JZ, Morgan J, Tesch GH, Rickard AJ, Chrissobolis S, Drummond GR, Fuller PJ, Young MJ. Cardiac tissue injury and remodeling is dependent upon $\mathrm{mr}$ regulation of activation pathways in cardiac tissue macrophages. Endocrinology. 2016;157:3213-23.

54. Rosenkranz S. Tgf-beta1 and angiotensin networking in cardiac remodeling Cardiovasc Res. 2004;63:423.

55. Kuwahara F, Kai H, Tokuda K, Kai M, Takeshita A, Egashira K, Imaizumi T. Transforming growth factor- $\beta$ function blocking prevents myocardial fibrosis and diastolic dysfunction in pressure-overloaded rats. Circulation. 2002;106:130-5.

56. Hu C, Dandapat A, Sun L, Khan JA, Liu Y, Hermonat PL, Mehta JL. Regulation of tgfbeta1-mediated collagen formation by lox-1: studies based on forced overexpression of tgfbeta1 in wild-type and lox-1 knock-out mouse cardiac fibroblasts. J Biol Chem. 2008:283:10226-31.

57. Dobaczewski M, Chen W, Frangogiannis NG. Transforming growth factor (tgf)- $\beta$ signaling in cardiac remodeling. J Mol Cell Cardiol. 2011:51:600-6.

58. Kodavanti UP, Schladweiler MC, Gilmour PS, Wallenborn JG, Mandavilli BS, Ledbetter AD, Christiani DC, Runge MS, Karoly ED, Costa DL. The role of particulate matter-associated zinc in cardiac injury in rats. Environ Health Perspect. 2008;116:13-20

59. Lu X, Zhu Y, Bai R, Li S, Teng X. The effect of manganese-induced toxicity on the cytokine mrna expression of chicken spleen lymphocytes in vitro. Res Vet Sci. 2015;101:165-7.

60. Shao JJ, Yao HD, Zhang ZW, Li S, Xu SW. The disruption of mitochondrial metabolism and ion homeostasis in chicken hearts exposed to manganese. Toxicol Lett. 2012;214:99-108.

61. Ku T, Zhang Y, Ji X, Li G, Sang N. Pm2.5-bound metal metabolic distribution and coupled lipid abnormality at different developmental windows. Environ Pollut. 2017:228:354.

62. Cuevas AK, Niu J, Zhong M, Liberda EN, Ghio A, Qu Q, Chen LC. Metal rich particulate matter impairs acetylcholine-mediated vasorelaxation of microvessels in mice. Part Fibre Toxicol. 2015;12:14. 
63. Kim YH, Tong H, Daniels M, Boykin E, Krantz QT, Mcgee J, Hays M, Kovalcik K, Dye JA, Gilmour Ml. Cardiopulmonary toxicity of peat wildfire particulate matter and the predictive utility of precision cut lung slices. Part Fibre Toxicol. 2014:11:29.

64. Miller MR, Mclean SG, Duffin R, Lawal AO, Araujo JA, Shaw CA, Mills NL, Donaldson K, Newby DE, Hadoke PW. Diesel exhaust particulate increases the size and complexity of lesions in atherosclerotic mice. Part Fibre Toxicol. 2013;10:61.

65. Fink GD. Does tail-cuff plethysmography provide a reliable estimate of central blood pressure in mice? J Am Heart Assoc. 2017;6:e006554.

66. Chen M, Li B, Sang N. Particulate matter (pm2.5) exposure seasondependently induces neuronal apoptosis and synaptic injuries. J Environ Sci. 2017:54:336-45.

67. Bradford MM. A rapid and sensitive method for the quantitation of microgram quantities of protein utilizing the principle of protein-dye binding. Anal Biochem. 1976;72:248-54.

Ready to submit your research? Choose BMC and benefit from:

- fast, convenient online submission

- thorough peer review by experienced researchers in your field

- rapid publication on acceptance

- support for research data, including large and complex data types

- gold Open Access which fosters wider collaboration and increased citations

- maximum visibility for your research: over $100 \mathrm{M}$ website views per year

At BMC, research is always in progress.

Learn more biomedcentral.com/submissions 